\title{
PELATIHAN DAN PENDAMPINGAN MENULIS EKSPRESIF UNTUK MENURUNKAN STRESS BAGI WARGA BINAAN WANITA RUMAH TAHANAN KELAS IIB PONOROGO
}

\author{
Fadhilah Rahmawati \\ Fakultas Usuhulludin, Adab, dan Dakwah IAIN Ponorogo \\ fadhila.iainpo@gmail.com \\ Agus Romdlon Saputra \\ Fakultas Usuhulludin, Adab, dan Dakwah IAIN Ponorogo \\ dodonsaputra@gmail.com
}

\begin{abstract}
Abstrack
The aim of the study is to drive the women prisoner of Rumah Tahanan Kelas IIB Ponorogo having mental skill especially stress management by using expressive writing, for go through the periode of prisoned and back to society. Being prisoner tend to draw the women prisoner feel stressed cause of limited access of others, bored to face and through the prison daily activities, and psychological upheaval of their criminal offense. There for, having a stress management as a mental skill are needed for them as a strategy to decrease stress level at low to medium level, and pursuit the wellbeing. Method used are participation action research. Finding of the study are expressive writing awareness emerged and motivation to use expressive writing as stress management increased.
\end{abstract}

Keywords: women prisoner; mental skill; expressive writing; wellbeing

\begin{abstract}
Abstrak
Studi ini bertujuan untuk mendorong warga binaan wanita Rumah Tahanan Kelas IIB Ponorogo untuk memiliki mental skill dalam stress management, baik selama berada di rumah tahanan maupun nantinya setelah menyelesaikan masa tahanan dan kembali ke tengah masyarakat. Berada di rumah tahanan seringkali membuat warga binaan merasa tertekan karena interaksi dengan pihak luar yang dibatasi, kebosanan menghadapi dan menjalani aktivitas rumah tahanan, serta pergolakan batin atas kasus pelanggaran pidana mereka. Oleh sebab itu, manajemen stres merupakan mental skill yang sangat diperlukan warga binaan untuk dimiliki sebagai salah satu strategi menurunkan level stres tingkat rendah-medium, dan meningkatkan level kesejahteraan (wellbeing). Metode yang digunakan adalah participatory action research (PAR). Temuan studi ini di antaranya munculnya
\end{abstract}


kesadaran urgensi mental skill menulis ekspresif dan motivasi menggunakan metode ini untuk mengelola stres di kemudian hari.

Kata kunci: warga binaan wanita; mental skill; menulis ekspresif; kesejahteraan

\section{PENDAHULUAN}

Bagi masyarakat, narapidana dikenal sebagai orang yang terlibat dengan kejahatan atau perbuatan kriminal dan cenderung dianggap sebagai orang-orang yang negatif. Stigma ini menimbulkan sikap abai terhadap para narapidana. Bagi narapidana, stigma masyarakat tersebut menimbulkan efek psikologis yang berat. Mereka merasa telah dibuang dari masyarakat, tidak memiliki masa depan, sehingga mudah merasa tertekan atau merasa stres.

Berada dalam Rumah Tahanan sebagai tahanan, para warga binaan merasakan dampak psikologis yang cukup berat. Rumah tahanan kelas IIB sebagai salah satu bagian dalam sistem peradilan pidana membatasi kebebasan para tahanan untuk kontak dengan masyarakat luar. Dikarenakan kehilangan kebebasan, sebagaimana dalam studi Soewaryo, rutan sendiri menjadi faktor pemicu stres yang utama bagi para warga binaan ${ }^{1}$.

Stres menunjukkan kondisi tekanan yang dirasakan oleh individu yang disebabkan oleh situasi tertentu. Stres dapat muncul dari faktor pencetus baik internal atau eksternal diri individu ${ }^{2}$. Stres yang menetap berisiko menjadikan individu yang mengalaminya berpotensi berkembang menjadi patologis. Kondisi ini jika tidak segera di atasi akan berdampak buruk pada kesejahteraan individu tersebut ${ }^{3}$.

Menurut Soewaryo ${ }^{4}$, rumah tahanan merupakan faktor pemicu stres yang utama bagi para tahanan. Dirundung berbagai perasaan seperti kesepian, sesal, rasa bersalah, pesimisme, kehilangan harapan akan masa depan, putus asa, juga sering

\footnotetext{
1 Soewaryo, Yenny Nusuantari. “Hubungan Dukungan Sosial Dengan Tingkat Stres Pada Narapidana Di Rumah Tahanan Situbondo." PhD Thesis, University of Muhammadiyah Malang, 2006.

2 Wiwin Hendriani, Resiliensi Psikologis Sebuah Pengantar, Pertama (Jakarta: Prenadamedia Grup, 2018

${ }^{3}$ Naning Pranoto, Writing for Therapy: Menyembuhkan Luka Emosi, Galau, Patah Hati, Luka Hati, Luka Jiwa Dengan Kata-Kata (Jakarta: Yayasan Pustaka Obor Indonesia, 2015).

4 Soewaryo, "Hubungan Dukungan Sosial Dengan Tingkat Stres Pada Narapidana Di Rumah Tahanan Situbondo."
} 
dirasakan sehingga menjadi sumber stres selama menjalani masa tahanan. Tingkat stress tahanan dipengaruhi oleh gender, usia, dan lama masa tahanan ${ }^{5}$. Kondisi stres selain berdampak secara fisik juga berdampak terhadap tubuh, salah satunya ambang nyeri yang dirasakan oleh warga binaan ${ }^{6}$.

Menulis ekspresif sebagai salah satu terapi psikologis dapat menjadi pilihan untuk menurunkan stres. Jenis terapi ini mendorong partisipan untuk secara bebas menuangkan kegelisahan dan berbagai wujud stres yang mereka rasakan, dengan menuliskannya. Secara teknis, menulis ekspresif cukup mudah untuk dilakukan para warga binaan karena tidak memerlukan keterampilan khusus. Dukungan yang diperlukan adalah kesediaan para partisipan untuk berpartisipas secara sukarela ${ }^{7}$.

Studi Putri ${ }^{8}$ menunjukkan adanya pengurangan beban fisik, emosional, dan psikologis pada narapidana remaja setelah melakukan menulis ekspresif. Studi Soewaryo $^{9}$, menunjukkan tidak ada hubungan dukungan sosial dan tingkat stres. Institusi rumah tahananlah yang cenderung menjadi stressor stres yang utama para terpidana.

Stres menunjukkan kondisi tekanan yang dirasakan oleh individu yang disebabkan oleh situasi tertentu. Stres dapat muncul dari faktor pencetus baik internal atau eksternal diri individu ${ }^{10}$. Terdapat tiga jenis stres menurut Middlebrooks dan Audage ${ }^{11}$, yaitu: (1) stres positif, dihasilkan dari pengalaman terhadap kesulitan atau ketidaknyamanan yang terjadi dalam waktu singkat. Stres jenis ini termasuk dalam kategori normal. (2) stres yang dapat ditoleransi, lebih intens daripada stres positif, berlangsung dalam waktu singkat, dan umumnya

\footnotetext{
55 Milda Wahyu Nuria, "Perbedaan Tingkat Stres Narapidana Di Lembaga Pemasyarakatan Klas IIA Jember Di Tinjau Dari Lama Vonis" (PhD Thesis, Universitas Muhammadiyah Jember, 2016). 6 Ira Anggar Kusuma, “Gambaran Hubungan Stres Psikososial Dan Nilai Ambang Nyeri Gigi Pada Tahanan Di Rumah Tahanan Kelas I Surabaya" (Phd Thesis, Universitas Airlangga, 2013).

7 Pranoto, Writing for Therapy: Menyembuhkan Luka Emosi, Galau, Patah Hati, Luka Hati, Luka Jiwa Dengan Kata-Kata.

8 Ayu Kumala Eka Putri, "Pengaruh Menulis Ekspresif Terhadap Copingpada Narapidana Remaja" (PhD Thesis, Universitas Islam Negeri Sultan Syarif Kasim Riau, 2015).

9 Soewaryo, "Hubungan Dukungan Sosial Dengan Tingkat Stres Pada Narapidana Di Rumah Tahanan Situbondo."

10 Wiwin Hendriani, Resiliensi Psikologis Sebuah Pengantar, Pertama (Jakarta: Prenadamedia Grup, 2018

11 Jennifer S. Middlebrooks and Natalie C. Audage, "The Effects of Childhood Stress on Health across the Lifespan" (National Center for Injury Prevention and Control of the Centers for Disease..., 2008).
} 
dapat diatasi. Jika kondisi stres jenis ini menetap dapat berkembang menjadi stres toksik. (3) Stres toksik, dihasilkan dari pengalaman terhadap kesulitan atau ketidaknyamanan yang intens dan berlangsung dalam jangka waktu yang lama (bertahun-tahun). Stres toksik jenis yang paling berat daripada dua jenis lainnya dan termasuk sulit untuk diatasi.

Terapi menulis ekspresif bekerja dengan baik salah satunya untuk meringankan gejala untuk gangguan mental dalam kategori ringan hingga menengah, salah satunya stress sebagaimana dikategorikan oleh Middlebrook di atas. Studi menunjukkan bahwa menulis ekspresif berpengaruh positif bagi kesehatan fisik dan mental bagi individu yang pernah mengalami peristiwa traumatik $^{12},{ }^{13}$.

Permasalahan yang hendak diurai dalam studi ini adalah mendeskripsikan permasalahan yang dihadapi oleh warga binaan Rumah Tahanan terkait dengan penanganan kesehatan mental dan refleksi menulis ekspresif untuk menurunkan stres warga binaan wanita.

\section{METODE PENELITIAN}

Metode yang digunakan dalam penelitian ini adalah participatory action research (PAR), yaitu implementasi suatu penelitian terhadap proses perubahan sosial.

\section{HASIL PNELITIAN DAN PEMBAHASAN}

Menurut Harrington, stres adalah kumpulan reaksi kognitif, emosi, fisiologi, dan perilaku terhadap pengalaman organisme untuk menghadapi ancaman dan tantangan yang dirasakan ${ }^{14}$. Sebagai sebuah kumpulan reaksi, maka stres melibatkan berbagai unsur pada diri individu, baik fisik maupun nonfisik.

12 Dzatalina Diya Azhima and Endang Sri Indrawati, "Hubungan Antara Dukungan Sosial Keluarga Dengan Subjective Well-Being Pada Narapidana Di Lembaga Pemasyarakatan" X"” (PhD Thesis, Undip, 2018).

13 Ayu Kumala Eka Putri, "Pengaruh Menulis Ekspresif Terhadap Copingpada Narapidana Remaja" (PhD Thesis, Universitas Islam Negeri Sultan Syarif Kasim Riau, 2015).

14 Harrington, Rick. Stress, Health, EWell-Being: Thriving in The 21st Century. Wadworth Cengage: United State. 2013: 8 
Richard Lazarus memperluas definisi stres dengan melihat hubungan antara manusia dan lingkungannya ${ }^{15}$. Manusia dengan karakternya di satu sisi dan kondisi alamiah lingkungan di sisi lain. Dua hal ini memiliki peran dalam memunculkan stres pada individu. Sehingga tidaklah mungkin untuk mengkaji stres tanpa melibatkan dua hal penting tersebut.

Terdapat tiga jenis stres menurut Middlebrooks dan Audage ${ }^{16}$, yaitu: (1) stres positif, dihasilkan dari pengalaman terhadap kesulitan atau ketidaknyamanan yang terjadi dalam waktu singkat. Stres jenis ini termasuk dalam kategori normal. (2) stres yang dapat ditoleransi, lebih intens daripada stres positif, berlangsung dalam waktu singkat, dan umumnya dapat diatasi. Jika kondisi stres jenis ini menetap dapat berkembang menjadi stres toksik. (3) Stres toksik, dihasilkan dari pengalaman terhadap kesulitan atau ketidaknyamanan yang intens dan berlangsung dalam jangka waktu yang lama (bertahun-tahun). Stres toksik jenis yang paling berat daripada dua jenis lainnya dan termasuk sulit untuk diatasi.

Sebagaimana Lazarus, Hans Selye juga tidak selalu memandang stres sebagai sesuatu hal yang melulu negatif. Selye membedakan stres dalam distress sebagai stres negatif dan eustress sebagai stres positif. Eustress timbul dengan gejala atau tanda yang menyerupai stres namun memberikan efek gembira, termotivasi, dan menyenangkan ${ }^{17}$.

Dalam participatory action research ini, warga binaan dipandang sebagai bagian dari masyarakat yang perlu diperlakukan secara adil. Walaupun mereka melakukan pelanggaran pidana yang merugikan masyarakat. Masih terdapat potensi kemanusiaan yang perlu dihidupkan kembali.

Tahapan yang dilalui dalam studi ini meliputi riset pendahuluan yang dilakukan melalui laporan mahasiswa magang dan kunjungan ke lokasi penelitian. Dalam kunjungan-kunjungan berikutnya dilakukan analisis lalu merumuskan masalah, yaitu diperoleh bahwa masalah partisipan selama ini adalah kurangnya

15 Lazarus, Richard S. \& Folkman, Susan. Stress, Appraisal, \& Coping. Springer Publishing Company: New York. 1984: 21.

16 Jennifer S. Middlebrooks and Natalie C. Audage, "The Effects of Childhood Stress on Health across the Lifespan" (National Center for Injury Prevention and Control of the Centers for Disease..., 2008).

17 Harrington, Rick. Stress, Health, EWell-Being: Thriving in The 21st Century. Wadworth Cengage: United State. 2013: 4 
layanan dan minimnya keterampilan untuk mengelola stress secara mandiri, terutama selama masa pandemi yang sebagian besar layanan dari pengelola rumah tahanan dikurangi sebagai bagian dari pengetatan protokol Covid-19.

Selanjutnya dilakukan perencanaan tindakan dengan salah satu gagasan yang muncul yang kemudian dikerucutkan adalah perlunya para warga binaan mengakuisisi manajemen stress secara mandiri. Terutama dengan adanya dukungan sumber daya maupun potensi, di antaranya mampu membaca-menulis, adanya semangat untuk memperbaiki diri, serta kemauan atau motivasi untuk belajar.

Aksi yang dilaksanakan adalah partisipan secara aktif mendorong diri untuk mempelajari skil baru dalam hal mengelola stress yang dirasakan, secara mandiri. Dengan keterampilan mental baru ini mereka mampu menjadi solusi atas permasalahan yang mereka hadapi tanpa harus bergantung pada keberadaan layanan konseling atau psikologi. Terutama pada masa pandemi yang pada masa ini akses bertemu keluarga, sebagai salah satu social support mereka, jauh berkurang baik secara kualitatif maupun kuantitatif.

Untuk mendukung pelaksanaan aksi, dipilih prosedur menulis ekspresif yang dikembangkan oleh James Pennebaker. Prosedur ini meliputi aktivitas menulis ekspresif yang dilakukan secara sekuensial dalam empat sesi berturut-turut. Pada akhir setiap sesi, partisipan secara mandiri mengevaluasi capaian menulis mereka secara kuantitatif maupun kualitatif.

Adapun sesi menulis ekspresif yang diberikan kepada partisipan merupakan sesi basic sebagaimana pada table berikut:

\section{Tabel 1}

\section{Instruksi dalam menulis ekspresif pada tiap sesi}

\begin{tabular}{llll}
\hline Sesi & Instruksi & Target & \\
\hline Hari 1 & Tulislah pikiran atau perasaan Anda & Mampu menuliskan \\
& yang paling dalam tentang trauma atau pergolakan emosi yang \\
& pergolakan emosi yang paling dirasakan, bersedia & and \\
& berpengaruh dalam hidup Anda. & terbuka (self-disclosure) \\
& Misalnya, hal-hal membuat Anda & \\
& sangat sakit hati sehingga rasanya \\
& tidak mungkin memaafkan & \\
\hline
\end{tabular}




\begin{tabular}{|c|c|c|}
\hline Hari 2 & $\begin{array}{l}\text { Tulislah pikiran atau perasaan Anda } \\
\text { yang paling dalam tentang trauma atau } \\
\text { pergolakan emosi yang paling } \\
\text { berpengaruh dalam hidup Anda }\end{array}$ & \begin{tabular}{lrr} 
Mampu & \multicolumn{2}{r}{ menuliskan } \\
pergolakan & emosi & yang \\
dirasakan & secara & lebih \\
mendetail & &
\end{tabular} \\
\hline Hari 3 & $\begin{array}{l}\text { Cobalah mengambil sudut pandang } \\
\text { yang berbeda, sisi lain, atau bagian } \\
\text { lain dari peristiwa atau trauma yang } \\
\text { telah Anda tulis sebelumnya. Fokuslah } \\
\text { pada emosi, pikiran atau perasaan } \\
\text { Anda yang paling dalam tentang } \\
\text { trauma atau pergolakan emosi yang } \\
\text { paling berpengaruh dalam hidup Anda } \\
\text { saat ini }\end{array}$ & $\begin{array}{l}\text { Mampu melihat sisi lain } \\
\text { permasalahan yang } \\
\text { dimiliki, memandang dari } \\
\text { perpspektif yang berbeda }\end{array}$ \\
\hline Hari 4 & $\begin{array}{l}\text { Akhiri seluruh peristiwa yang } \\
\text { menyakitkan, emosi, pikiran, dan } \\
\text { perasaan yang telah Anda ungkapkan } \\
\text { ke dalam sebuah kisah penuh makna, } \\
\text { menurut versi Anda sendiri, yang akan } \\
\text { Anda bawa ke masa depan }\end{array}$ & $\begin{array}{l}\text { Mampu mengambil } \\
\text { hikmah tertentu dari } \\
\text { peristiwa } \\
\text { traumatis/pergolakan } \\
\text { batin yang dialami }\end{array}$ \\
\hline
\end{tabular}

Dari 18 orang partisipan yang mengikuti menulis ekspresif, berikut output yang diperoleh dideskripsikan dalam tabel 2.

Tabel 2

Output partisipan tiap sesi

\begin{tabular}{ccl}
\hline Sesi & Kesertaan & \multicolumn{1}{c}{ Output } \\
\hline Hari ke 1 & 18 partisipan & $\begin{array}{l}\text { Mampu menuliskan pergolakan emosi yang } \\
\text { dirasakan dengan baik, bersedia terbuka, } \\
\text { menulis minimal 2 paragraf, memahami } \\
\text { instruksi dengan baik. }\end{array}$ \\
Hari ke 2 & 18 partisipan & $\begin{array}{l}\text { Mampu menuliskan pergolakan emosi yang } \\
\text { dirasakan dengan baik, belum mampu } \\
\text { mengembangkan tulisan dengan baik, } \\
\text { menulis minimal 2 paragraf, memahami } \\
\text { instruksi dengan baik. } \\
\text { Hari ke 3 }\end{array}$ \\
& & $\begin{array}{l}\text { Perspektif yang berbeda sudah mereka } \\
\text { ungkapkan mulai sesi hari pertama, bagian } \\
\text { ini secara instruksi belum dipahami dengan } \\
\text { baik, hasilnya kurang sesuai dengan } \\
\text { instruksi. }\end{array}$
\end{tabular}




\begin{tabular}{ll}
\hline Hari ke 4 18 partisipan & Mampu mengenali dengan baik permalahan \\
& mereka sendiri. Mampu membuat penutup \\
& atas pergolakan emosi atau trauma yang \\
& dialami dengan kalimat-kalimat harapan atau \\
& keinginan pada masa depan atau setelah \\
& menyelesaikan masa tahanan.
\end{tabular}

Selain pencapaian target berupa penguasaan cara atau teknik menulis ekspresif, peneliti juga menargetkan kesediaan partisipan untuk menggunakan teknik menulis ekspresif untuk mereduksi stressnya secara mandiri pada kesempatan berikutnya.

Berikut ini tabel kesediaan partisipan untuk menggunakan teknik menulis ekspresif pada kesempatan lain.

\section{Tabel 3}

\section{Kesediaan partisipan menggunakan teknik menulis ekspresif}

\begin{tabular}{lll}
\hline $\begin{array}{l}\text { No } \\
\text { partisipasi }\end{array}$ & $\begin{array}{l}\text { Bersedia } \\
\text { menggunakan } \\
\text { teknik menulis } \\
\text { ekspresif }\end{array}$ & Pernyataan \\
\hline 1 & Mungkin & Bisa jadi \\
2 & Ya & Ya \\
3 & Ya & Ya \\
4 & Ya & Ya \\
5 & - & - \\
6 & Mungkin & Mungkin \\
7 & Ya & Ya \\
8 & Ya & Ya \\
9 & Ya & Iya, aku akan selalu menulis apa yang aku alami di sini \\
10 & Tidak & Tidak \\
11 & Ya & InsyaAllah \\
12 & Mungkin & Bisa jadi \\
13 & Tidak & Tidak \\
14 & Ya & insyaAllah \\
15 & Ya & Saya berharap kesempatan ini ada lagi \\
16 & Tidak & Tidak \\
17 & Ya & Ya \\
19 & - & - \\
\hline
\end{tabular}

Data table 3 di atas direkapitulasi menjadi tabel 4 
Tabel 4

\section{Rekapitulasi kesediaan partisipan menggunakan teknik menulis ekspresif}

\begin{tabular}{lc}
\hline Kesediaan & Jumlah \\
\hline Ya & 10 \\
Tidak & 3 \\
Mengambang & 3 \\
Tidak menjawab & 2 \\
\multicolumn{1}{r}{ Total } & $\mathbf{1 8}$ \\
\hline
\end{tabular}

18 orang partisipan yang hadir pada hari pertama, juga hadir pada tiga hari berikutnya. Mereka dengan tertib mengikuti arahan peneliti dan petugas rumah tahanan sebagai mitra pengabdi. Partisipasi aktif pada setiap sesi. Praktik menulis ekspresif ini dilaksanakan selama empat hari berturut-turut.

Masing-masing hari merupakan satu sesi. Partisipan mengikuti sesi-sesi berturut-turut. Satu sesi diselesaikan dalam satu hari. Mereka mendapatkan waktu selama 20 menit setiap sesinya. Dengan alat tulis yang telah disediakan mereka menyelesaikan setiap sesi sesuai instruksi dengan baik.

Dari para warga binaan, dapat diketahui bahwa mereka memiliki pengalaman baik traumatis maupun menyakitkan yang menimbulkan luka batin dalam waktu yang cukup lama. Beberapa memiliki masalah tersebut sedari masih anak-anak, yang karena berbagai situasi atau kondisi tidak tertangani dengan baik, memengaruhi pola tindakan dan pemikiran mereka sebagai orang dewasa.

Hampir semua warga binaan memendam perasaan bersalah atas tindakan melanggar hukum, meninggalkan peran mereka sebagai istri, ibu, dan anak, serta bertekad untuk melaksanakan peran-peran tersebut sekembalinya berkumpul bersama keluarga nantinya. Perasaan bersalah ini juga mendorong mereka untuk bertahan menjalani masa tahanan dengan baik.

Hasil menulis menunjukkan para partisipan menyambut baik dan mempersepsi positif pelatihan menulis ekspresif ini. Instruksi atau petunjuk yang diberikan dapat dipahami dengan baik. Setiap sesinya berlangsung sesuai dengan prosedur. Artinya, seusai program pelatihan dan pendampingan ini, partisipan atau warga binaan dapat melakukan menulis ekspresif ini secara mandiri. Dengan 
demikian, tanpa bantuan atau keterlibatan orang lain, mereka dapat melakukan teknik ini.

Dari tabel di atas, ketercapaian program ini belum sepenuhnya berhasil. 13 partisipan dari total 18 orang, menyatakan mereka bersedia menggunakan menulis ekspresif untuk menurunkan level stres mereka. Artinya capaian program aksi ini $72,2 \%$ tercapai.

\section{PENUTUP}

Dari pemaparan data dan pembahasan dapat disimpulkan (1) Warga binaan wanita Rumah Tahanan Negara Kelas IIB Ponorogo memiliki stres maupun pergolakan emosi yang terpendam. Stres yang dirasakan bersumber dari pelanggaran tindak pidana yang menyebabkan keberadaan mereka di rumah tahanan, jauh dari keluarga, dan kejenuhan berada di rumah tahanan dan (2) Setelah mendapatkan pelatihan dan praktik secara langsung, warga binaan wanita Rumah Tahanan Negara Kelas IIB Ponorogo telah mampu melakukan menulis ekspresif secara mandiri.

Adapun untuk para peneliti berikutnya, disarankan untuk (1) Melakukan pendekatan personal yang lebih dalam terhadap partisipan sehingga mereka merasa lebih memahami pentingnya menulis ekspresif sebagai salah satu bentuk terapi mandiri dan (2) perlu rancangan prosedur yang lebih baik yang sesuai bila pelatihan ini dilaksanakan pada saat pandemi.

\section{DAFTAR RUJUKAN}

Azhima, Dzatalina Diya, and Endang Sri Indrawati. "Hubungan Antara Dukungan Sosial Keluarga Dengan Subjective Well-Being Pada Narapidana Di Lembaga Pemasyarakatan" X".” PhD Thesis, Undip, 2018.

Ekasari, Agustina, and Nova Dhelia Susanti. "Hubungan Antara Optimisme Dan Penyesuaian Diri Dengan Stress Pada Narapidana Kasus NAPZA Di Lapas Kelas IIA Bulak Kapal Bekasi." SOUL: Jurnal Ilmiah Psikologi 2, no. 2 (2009): 1-32.

Hapsari, Ayu Dyah, and Sofia Retnowati. "Pengaruh Menulis Ekspresif Terhadap Simtom-Simtom Gangguan Stres Pasca Trauma Pada Perempuan Korban 
Kekerasan Dalam Rumah Tangga.” PhD Thesis, Universitas Gadjah Mada, 2012.

Harrington, Rick. Stress, Health, \&Well-Being: Thriving in The $21^{\text {st }}$ Century. Wadworth Cengage: United State. 2013: 8.

Hendriani, Wiwin. Resiliensi Psikologis Sebuah Pengantar. Pertama. Jakarta: Prenadamedia Grup, 2018.

Katoppo, Martin L., and Iwan Sudradjat. "Combining Participatory Action Research (PAR) and Design Thinking (DT) as an Alternative Research Method in Architecture." Procedia - Social and Behavioral Sciences, Reflections On Creativity: Public Engagement And The Making Of Place, 184 (May 20, 2015): 118-25. https://doi.org/10.1016/j.sbspro.2015.05.069.

Kusuma, Ira Anggar. "Gambaran Hubungan Stres Psikososial Dan Nilai Ambang Nyeri Gigi Pada Tahanan Di Rumah Tahanan Kelas I Surabaya." Phd Thesis, Universitas Airlangga, 2013.

Lazarus, Richard S. \& Folkman, Susan. Stress, Appraisal, \& Coping. Springer Publishing Company: New York. 1984.

Middlebrooks, Jennifer S., and Natalie C. Audage. "The Effects of Childhood Stress on Health across the Lifespan." National Center for Injury Prevention and Control of the Centers for Disease ..., 2008.

Nuria, Milda Wahyu. "Perbedaan Tingkat Stres Narapidana Di Lembaga Pemasyarakatan Klas IIa Jember Di Tinjau Dari Lama Vonis." PhD Thesis, Universitas Muhammadiyah Jember, 2016.

Pranoto, Naning. Writing for Therapy: Menyembuhkan Luka Emosi, Galau, Patah Hati, Luka Hati, Luka Jiwa Dengan Kata-Kata. Jakarta: Yayasan Pustaka Obor Indonesia, 2015.

Putri, Ayu Kumala Eka. "Pengaruh Menulis Ekspresif Terhadap Coping pada Narapidana Remaja." Ph. D Thesis, Universitas Islam Negeri Sultan Syarif Kasim Riau, 2015.

Sexton, Janel D. \& Pennebaker, James W. The Healing Powers of Expressive Writing dalam Psychology of Creative Writing. Kaufman, Barry S. \& Kaufman James.

Soewaryo, Yenny Nusuantari. "Hubungan Dukungan Sosial Dengan Tingkat Stres Pada Narapidana Di Rumah Tahanan Situbondo." PhD Thesis, University of Muhammadiyah Malang, 2006. 